\title{
Corrigendum
}

\section{Non-TBI stem cell transplantation protocol for Fanconi anaemia using HLA-compatible sibling and unrelated donors}

J de la Fuente, S Reiss, M McCloy, T Vulliamy, IAG Roberts, A Rahemtulla and I Dokal

Bone Marrow Transplantation (2004) 34, 95. On page 654, right-hand column, first paragraph, the doi:10.1038/sj.bmt.1704590 following sentence was published incorrectly and should read as follows:

Secondly, in addition to CSA, for GVHD prophylaxis, Correction to: Bone Marrow Transplantation (2003) 32, 653-656. doi:10.1038/sj.bmt.1704219 patients received Campath- $1 \mathrm{H}$ (anti-CD52) $0.5 \mathrm{mg} / \mathrm{kg}$ $(0.1 \mathrm{mg} / \mathrm{kg} /$ day from day +1 to day +5$)$. 